\title{
Exploring the Construct of Learner Autonomy in Writing: The Roles of Motivation and the Teacher
}

\author{
Marine Yeung ${ }^{1}$ \\ ${ }^{1}$ School of Arts and Humanities, Tung Wah College, Hong Kong \\ Correspondence: Marine Yeung, School of Arts and Humanities, Tung Wah College, 90A, Shantung Street, \\ Mongkok, Kowloon, Hong Kong. Tel: 852-34686694. E-mail: marineyeung@twc.edu.hk
}

Received: May 22, 2016 Accepted: June 24, 2016 Online Published: June 26, 2016

doi: 10.5539/elt.v9n8p122 URL: http://dx.doi.org/10.5539/elt.v9n8p122

\begin{abstract}
Learner autonomy is widely recognized as a desirable educational goal in second language contexts. However, the lack of domain-specificity in research related to learner autonomy, compounded with the diverse views on its connotations, makes it difficult to either nurture or measure. This paper reports on a study that explored the construct of learner autonomy in the area of writing using quantitative data collected in the naturalistic settings of three secondary school classrooms in Hong Kong. In this study, learner autonomy was proposed as a construct consisting of autonomous attitudes including motivation, self-confidence and independence from the teacher, and autonomous skills embracing strategy use and metacognitive knowledge. A questionnaire was designed accordingly to measure changes in the participants after a writing programme that adopted the process writing approach, the potential of which in fostering traits of learner autonomy had been demonstrated in previous studies and was further explored in this study. Findings gathered through factor analysis on the questionnaire data, followed by a paired-sample t-test to investigate changes in the participants after the writing programme, suggest that a degree of independence from the teacher may possibly be a prerequisite for autonomy development in terms of writing skills, while motivation may have a more important role to play in its subsequent development.
\end{abstract}

Keywords: construct, learner autonomy, writing, ESL, teacher's role, motivation, secondary school, Hong Kong

\section{Introduction}

\subsection{Measuring and Nurturing Learner Autonomy}

Learner autonomy has been generally recognized as a goal to pursue or a desirable learning outcome in the field of education in recent decades (e.g. Benson, 1996; Benson \& Toogood, 2002; Benson \& Voller, 1997; Crabbe, 1993; Dickinson, 1992; Lamb \& Reinders, 2008). The diverse interpretations of this term and its rather generic application, however, make it difficult to foster and assess in the classroom.To address this, the present study, using data collected from three ESL writing classrooms in Hong Kong, explored the construct of learner autonomy in the area of writing.

The theoretical framework proposed in this study was inspired by Oxford's (2003) taxonomy of learner autonomy. In addition to the themes originally incorporated in the taxonomy, this proposed framework features the roles of the teacher and of various types of motivation, both of which are recurring themes in the discussion on autonomous learning. A questionnaire was designed based on this proposed framework and administered on 70 learners from the Hong Kong ESL classrooms. Factor analysis was then implemented on the data collected through the questionnaire to examine the relationships among the various components in the proposed construct. This paper mainly reports on findings derived from the exploration of the construct through the scaling procedure of the questionnaire, supported by changes among the student participants in the various aspects of learner autonomy after a writing programme that was designed to facilitate the development of autonomous skills and attitudes using the process approach.

\subsection{Exploring the Construct of Learner Autonomy}

\subsubsection{Defining Learner Autonomy}

There have been diverse approaches to the conceptualization of the concept and differences in views on the components of learner autonomy (e.g., Holec, 1981; Wenden, 1991; Scharle \& Szabó, 2000; Little, 1991; Benson, 
1996). While the classic definition of learner autonomy by Holec (1981) is still most widely cited, which specifies that to take charge of one's learning means to hold the responsibility for various aspects of learning, there is a growing interest in the affective and cognitive qualities underlying such ability to manage one's own learning. As Little $(2004 ; 2007)$ suggests, this view of learner autonomy can only be justified with consideration of the motivational and metacognitive knowledge that develops when learners take charge of their own learning. The present study therefore set out to explore the construct of learner autonomy from a psychological perspective with incorporation of the components of learner motivation and metacognitive knowledge.

The study focused on the area of writing in response to the growing interest in domain-specific theories of learning in recent decades (e.g. Van Oers, 1998; Mayer, 2002; Veronikas \& Shaughnessy, 2005). Learner autonomy is often used in a rather broad sense, referring to the learner's general attitudes and skills in learning. However, an autonomous language learner may not be equally autonomous in all aspects of language learning; also, for autonomy to be accessible to learners, we must be able to show that learners can and do take control over certain aspects of their learning within natural contexts of learning (Benson, 2001). Findings from this study will hopefully contribute to the domain specificity in the research of learner autonomy and inform theory and practice related to the teaching and learning of writing.

\subsubsection{A taxonomy of Learner Autonomy}

The taxonomy of learner autonomy posited by Oxford (2003) incorporates the major views and perspectives in the discussion on the concept. To amalgamate various definitions into a "macro-definition" using an approach which Benson (2007) metaphorically calls the "kaleidoscopic strategy", Oxford (2003) proposes a comprehensive taxonomy to address the clashes in the definition of "autonomy" as a situation, an attitude or an ability that exist among the works by different writers (e.g. Dickinson, 1987; Holec, 1981) and embrace various approaches of operationalization of the concept. The model is all-encompassing incorporating technical, psychological, sociocultural and political-critical perspectives on autonomy, with four important themes, namely context, agency, motivation, and learning strategies, running through each. It acknowledges learner autonomy as a multi-dimensional construct by embracing motivation, strategy use, context and agency as different aspects of it. The taxonomy, particularly its psychological perspective which sees autonomy as a combination of characteristics of the individual, provides important groundwork for this study.

\subsubsection{A proposed Construct of Learner Autonomy}

Among all the psychological characteristics of learner autonomy, motivation has been widely recognized as a precondition or the primary impetus for learner autonomy (e.g. Dickinson, 1995; Spratt, Humphreys, \& Chan, 2002; Ushioda, 1996, 2003). While motivation is acknowledged to be one aspect of learner autonomy in Oxford's (2003) taxonomy, the types of motivation in play are not specified. This study therefore incorporated various types of motivation for exploration. In addition to motivation, confidence to take responsibility is also considered to be another attitudinal factor underlining the willingness to take action (Littlewood, 1996), and psychological research has shown that autonomous learners have such characteristics as being highly motivated as well as self-efficacious (Oxford, 2003). Both motivation and self-confidence were therefore included as aspects of autonomous attitudes in the present conceptualization of learner autonomy.

Another component of the proposed construct, which is not covered in Oxford's (2003) taxonomy, was independence from the teacher. Although it is generally agreed that learner autonomy does not mean total independence from the teacher, there is little dispute that in order to foster the development of learner autonomy in the classroom, teachers have to learn to relinquish control to their students and "wean" their students away from dependence on the teacher (Sheerin, 1997, p. 63). The degree to which learners are dependent on the teacher is often considered to be indicative of their readiness to take up learning on their own. For example, in Benson's (2002) study, the first two stages of the long-term developmental process of the group of undergraduate learners' orientations to English were characterized by decreasing dependence on teachers, with the first stage involving "learning what the teacher taught" and the second stage conceptualized as a process that involved individual effort and decision making under the directions of teachers (Benson, 2002, p. 20). Independence from the teacher was therefore considered to be one of the autonomous attitudes that should be incorporated in the construct for further exploration.

Learning strategies, which also constitute a theme of Oxford's (2003) taxonomy, are often viewed as a psychological gateway to L2 learner autonomy (Dickinson, 1992; Oxford, 1990, 2003; Wenden, 1991). The close ties between learner autonomy and strategy use have been recognized since the 1980s and the concept of language learning strategy had reached mainstream recognition by the beginning of 1990s as shown by the publication of some important works (e.g. O’Malley \& Chamot, 1990; Oxford, 1990; Wenden, 1991). Learning 
strategies refer to "specific actions, behaviours, steps, or techniques that students use to improve their own progress in developing skills in a second or foreign language. These strategies can facilitate the internalization, storage, retrieval or use of the new language" (Oxford, 1990, p. 518). Learning strategies are especially important for language learning because they are tools for active self-directed learning, and language learning is best facilitated by the development of greater independence on the part of the learner (Dickinson, 1992). These "tools" could therefore be viewed as strategies that develop alongside the autonomous attitudes. To facilitate the use of strategies, a learner needs to have metacognitive knowledge of such strategies, the task and themselves as learners; in other words, metacognitive knowledge (Wenden, 1998).

On the basis of the psychological aspect of Oxford's model of autonomy, and with reference to literature in learner autonomy as discussed above, learner autonomy was proposed as a construct embracing factors that constitute autonomous attitudes, including motivation, self-confidence and independence from the teacher, as well as those that constitute the enabling skills, including strategy use backed up with metacognitive knowledge. Since the study focused on the area of writing, mainly attitudes and skills related to writing and the learning of writing were considered. It is worth noting that although the concept of learner autonomy has been operationalized in different studies (e.g. Tassinari, 2012; Tanyeli \& Kuter, 2013), by far there have been limited empirical studies investigating learner autonomy as a construct consisting of all the factors above using a quantitative approach, and even fewer such studies focusing on the learning of writing. The current study, therefore, set out to fill a gap in the literature with practical implications.

\subsection{Research Questions}

The proposed construct of learner autonomy provided the general framework for data collection and analysis for the study. In order to explore the validity of this proposed construct, exploratory factor analysis and correlation tests were conducted in the scaling procedure of the questionnaire. This paper reports findings derived from the scaling procedure, which sought to answer the following questions pertaining to the validity of the construct:

- How do the factors correlate with each other in the pre-test and post-test?

- What inferences can be drawn from the results of the factor analysis concerning the roles of the teacher and of motivation?

\section{Methods}

\subsection{Setting and Participants}

The study was conducted in two schools, purposely selected on the basis of their representativeness of the local school context of Hong Kong in terms of the general academic performance of their students and the medium of instruction they adopted. At the time of the study, a local school banding system was in force, by which primary school leavers were allotted to secondary schools in five descending ranks; as the two participant schools fell into the middle bands rather than the highest or lowest bands, they were considered to represent the average secondary schools in Hong Kong. As for the medium of instruction, the two participating schools adopted Chinese as the medium of instruction (CMI), which is the major medium of instruction in over two-thirds of secondary schools in Hong Kong. It was believed that a study carried out in a CMI school would be more relevant to the local situation. All the participants were informed of the purpose of the study and the possible use of the data for scholarly publications, and they were aware that they could withdraw from the study at any point if they wished.

Of the three groups of students that participated in the study, one was a Secondary four class of 30 students in a CMI co-education secondary school, while the other two were from two Secondary one classes in a CMI girls' school with 19 and 21 students respectively. Altogether there were 70 student participants $(n=70,21$ males and 49 females), all Cantonese-speaking ethnic Chinese aged between 12 and 16. The information of the setting and participants of the study is shown in Figure 1 below. 


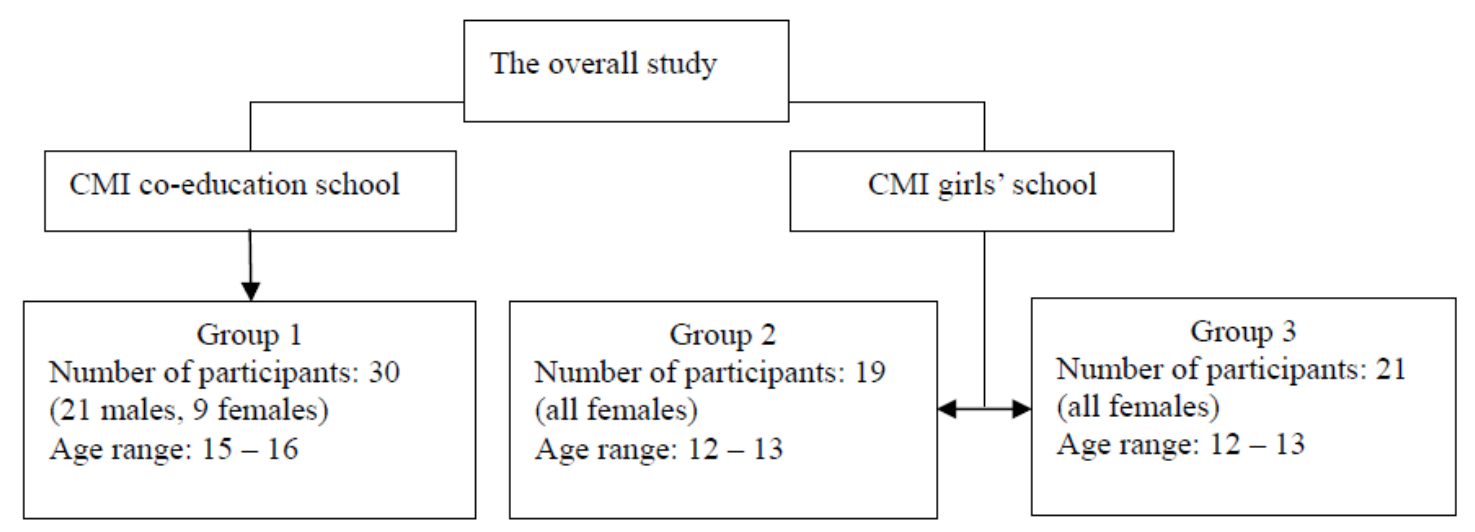

Figure 1. Setting and participants of the study

\subsection{Data Collection}

The questionnaire was administered in the naturalistic settings of the three classrooms. In each group, the participants were asked to complete the questionnaire (pre-test) prior to a writing programme in which the participants were subject to writing instruction using the multiple-draft peer review process approach, completing three consecutive writing tasks within a course of three and a half months. Each writing task was completed within around a month's time following the cycle shown in Figure 2 below:

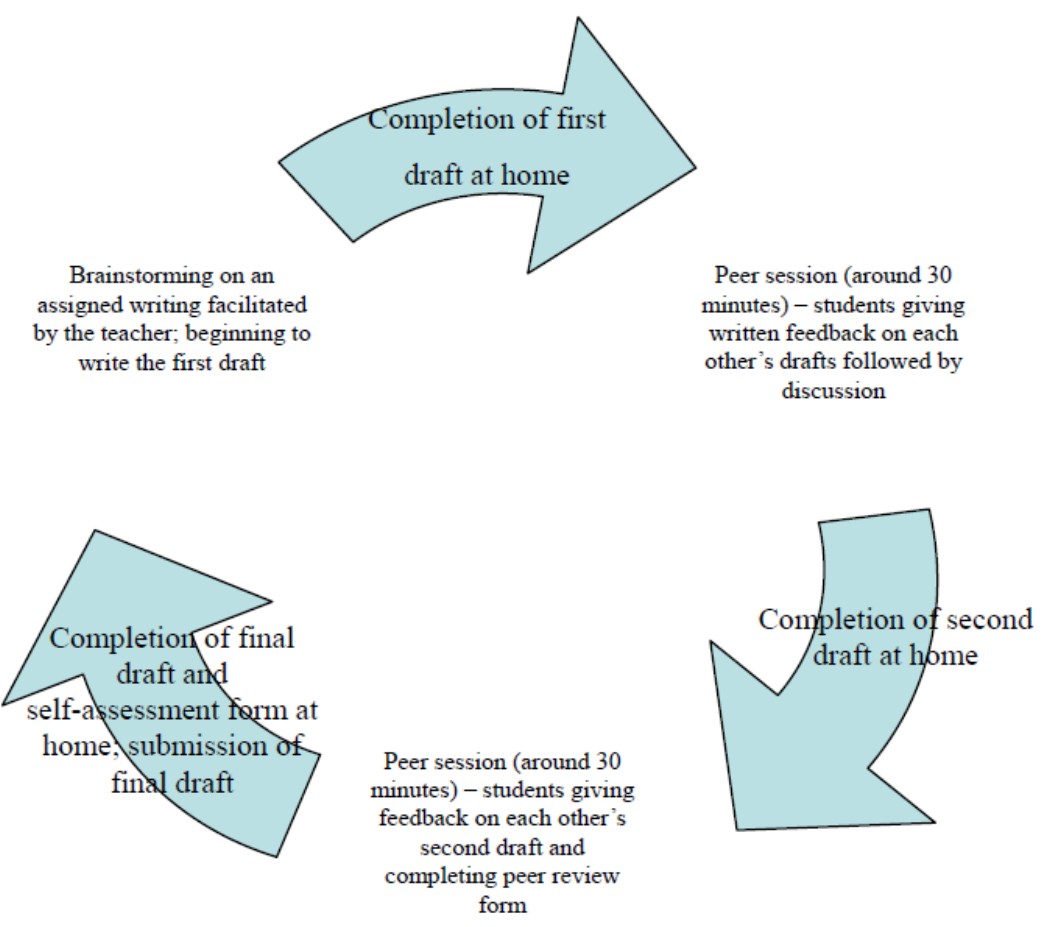

Figure 2. The process approach as adopted in the classes

The same questionnaire (post-test) was then administered again on the same participants upon completion of the programme to explore whether changes had taken place in terms of the participants' development of learner autonomy in the learning of writing.

To illuminate findings from the factor analysis, qualitative data were also collected through case studies, where data were collected from seven student participants from the three classes through interviews, writing journals 
and self-assessment forms for each writing task, and stimulated recall to find out about the participants' individual differences, approaches to writing and their reflections on the learning of writing. Although findings from the cases will not be discussed here, they are mentioned here to reflect the validity of the overall design of the study.

\subsection{The Questionnaire}

The questionnaire developed in this study was designed to measure students' readiness for autonomous learning of English writing. It was initially developed based on the conceptualization of learner autonomy in the area of writing with reference to the instrument developed by Cottrell (1995) on learner's readiness for autonomous learning, and Oxford's strategy inventory for language learning (SILL) (Oxford, 1990). As the participants of this study were young learners with limited linguistic competence in their L2, caution was taken to make sure the length and level of complexity of the instrument were manageable to them. The initial version was tested in a pilot study and then refined based on feedback from the participants and expert suggestions. The piloted English version was then translated into Chinese prior to implementation in the study.

The questionnaire was designed with writing as the focus. The initial pool of items of the refined version of the instrument included three sections with a total of 66 five-point Likert-scale questions $(1=$ strongly disagree to 5 $=$ strongly agree). Section 1 included 20 items that aimed to find out about the student's preparedness for autonomous learning, which included items that indicate motivation in learning English writing, perceived self-competence to do so, and independence from the teacher.

Section 2 asked about students' general approach to writing with reference to the model proposed by Flower and Hayes (1981) about expert composing process, which involves such recursive steps of planning, translating and revising. As more advanced writers tend to spend more time on planning and revising than novice writers, and feedback from others is often taken as input to facilitate revision, the 20 items of this section aimed to find out about the learners' practice in planning their writing, revising their drafts and seeking help and feedback from teachers and peers in the process of writing.

Section 3 comprised 26 questions about the writer's use of learning strategies. The types of strategies covered included general strategies to improve writing (direct strategies), metacognitive strategies and social strategies (indirect strategies) (cf. Oxford, 1990). As metacognitive knowledge is conceptualized as the prerequisite for self-directed learning, items about the writer's knowledge of himself/herself as a writer and the learning of writing were also included.

\section{Results}

\subsection{Factors Identified in the Factor Analysis of Data Collected from the Questionnaire}

The 70 student participants completed both the pre-test and the post-test questionnaires. The 70 completed questionnaires from the pre-test were put together for factor analysis, a procedure used to ascertain the fundamental structure of a set of indicator items (Pedhazur \& Schmelkin, 1991). Factor analysis was carried out on the post-test questionnaires collected from the same 70 students to ensure test-retest reliability. Based on the assumption that each of the three sections of the questionnaire represented one dimension of the overall construct of learner autonomy in writing, and each section consisted of several factors, exploratory factor analysis using principal components analysis with Varimax was conducted on each of the three sections. The KMO estimate of the sampling adequacy was all above 0.6 , with the Bartlett's Test of Sphericity score over 200 at $p=.000$. Only items with item-total correlation values of 0.4 or above, which indicate very good discrimination (Netemeyer, 2003), were accepted. Items were deleted based on their multiple loadings, relatively low item-total correlations or on theoretical grounds (refer to Appendix A for item-total correlations).

Three factors with Eigenvalues over 1 were extracted from each of the three sections of the questionnaire. The nine factors of learner autonomy in writing identified in the scaling procedure are as follows:

Self-directedness (SELFDIR), Motivation (MOTIV), Degree of Dependence on the Teacher (TDEP), Seeking Peer Help and Feedback (PEERB), Revision (REVIS), Planning (PLANING), Direct Strategies for Learning Writing (DIRSTR), Metacognitive Strategies and Knowledge (METASTR), Social Strategies Use (SOCSTR). The items of each factor are listed in Table 1 below. 
Table 1. The nine factors of learner autonomy in writing identified in the factor analysis

\begin{tabular}{|c|c|c|}
\hline Dimension & Factor & Items \\
\hline \multirow{12}{*}{$\begin{array}{l}\text { Autonomous } \\
\text { attitudes }\end{array}$} & \multirow{6}{*}{ Self-directedness } & $\begin{array}{l}\text { I seldom write in English except for school assignments, tests and } \\
\text { exams. }\end{array}$ \\
\hline & & I learn to write mainly for exams. \\
\hline & & I like writing in English. \\
\hline & & $\begin{array}{l}\text { I have studied English writing by myself, and I have learnt a lot } \\
\text { from this. }\end{array}$ \\
\hline & & I believe I have the ability to learn English writing well. \\
\hline & & $\begin{array}{l}\text { I believe that I can push myself to improve my English writing even } \\
\text { if there is no supervision. }\end{array}$ \\
\hline & \multirow{3}{*}{ Motivation } & Learning English writing will help me find jobs in future. \\
\hline & & $\begin{array}{l}\text { I need to learn English writing in order to communicate with } \\
\text { foreigners. }\end{array}$ \\
\hline & & I learn to write because writing is an important skill. \\
\hline & \multirow{3}{*}{$\begin{array}{l}\text { Degree of } \\
\text { Dependence on the } \\
\text { Teacher }\end{array}$} & I like the teacher to tell me what to write about. \\
\hline & & $\begin{array}{l}\text { The teacher should explain in detail the genre requirements of each } \\
\text { writing task. }\end{array}$ \\
\hline & & $\begin{array}{l}\text { When we write, the teacher should provide model essays as well as } \\
\text { vocabulary and sentence patterns related to the topic for our } \\
\text { reference. }\end{array}$ \\
\hline \multirow{11}{*}{$\begin{array}{l}\text { Autonomous } \\
\text { skills - General } \\
\text { writing strategies }\end{array}$} & \multirow{4}{*}{$\begin{array}{l}\text { Seeking Peer Help } \\
\text { and Feedback }\end{array}$} & $\begin{array}{l}\text { I ask my peers (classmates or friends) to give me feedback on my } \\
\text { writing. }\end{array}$ \\
\hline & & $\begin{array}{l}\text { I study seriously the feedback and suggestions given by my peers on } \\
\text { my writing. }\end{array}$ \\
\hline & & When I have difficulty in writing, I seek help from my peers. \\
\hline & & $\begin{array}{l}\text { If possible, I would discuss with classmates when working on a } \\
\text { writing task. }\end{array}$ \\
\hline & \multirow{5}{*}{ Revision } & $\begin{array}{l}\text { Even if the teacher does not ask me to, I revise my own writing until } \\
\text { I am satisfied with it. }\end{array}$ \\
\hline & & I always make drafts when doing writing tasks. \\
\hline & & $\begin{array}{l}\text { I use reference tools like dictionaries and grammar books when I } \\
\text { write. }\end{array}$ \\
\hline & & $\begin{array}{l}\text { When I revise my writing drafts, I first check the grammar and } \\
\text { spelling. }\end{array}$ \\
\hline & & $\begin{array}{l}\text { When I revise my writing drafts, I first check to see if the content } \\
\text { and organization can be improved. }\end{array}$ \\
\hline & \multirow[t]{2}{*}{ Planning } & $\begin{array}{l}\text { I think about the requirements of a writing task and then set a } \\
\text { writing goal before I actually write. }\end{array}$ \\
\hline & & I plan before I write. \\
\hline \multirow{4}{*}{$\begin{array}{l}\text { Autonomous } \\
\text { skills }- \text { Strategies } \\
\text { for } \quad \text { learning } \\
\text { writing }\end{array}$} & \multirow{4}{*}{$\begin{array}{l}\text { Direct Strategies } \\
\text { for Learning } \\
\text { Writing }\end{array}$} & I have my own way of generating writing ideas \\
\hline & & I look for ideas for writing outside the writing class \\
\hline & & $\begin{array}{l}\text { When I do English writing, I practise using different sentence } \\
\text { patterns, vocabulary and expressions. }\end{array}$ \\
\hline & & When I do English writing, I like experimenting with new ideas or \\
\hline
\end{tabular}




\begin{tabular}{|c|c|}
\hline & writing techniques. \\
\hline & I select examples of good writing to read. \\
\hline & If the writing is good, I know it and I know what makes it good. \\
\hline & $\begin{array}{l}\text { Even if I am not under supervision, I would still urge myself to } \\
\text { learn writing. }\end{array}$ \\
\hline & I look for chances to practise writing outside the classroom \\
\hline \multirow{6}{*}{$\begin{array}{l}\text { Meta-cognitive } \\
\text { Strategies and } \\
\text { Knowledge }\end{array}$} & $\begin{array}{l}\text { I know what types of composition I am supposed to learn to write in } \\
\text { each school year. }\end{array}$ \\
\hline & I clearly understand the requirements of each type of writing. \\
\hline & I have clear and concrete learning goals in writing. \\
\hline & I know how to improve my own writing. \\
\hline & I clearly know my strengths and weaknesses in the area of writing. \\
\hline & $\begin{array}{l}\text { I clearly know my English writing level compared with other } \\
\text { students in the class. }\end{array}$ \\
\hline \multirow{2}{*}{ Social Strategy Use } & I don't like other people to read my writing. \\
\hline & I don't like asking others questions related to writing. \\
\hline
\end{tabular}

\subsection{Internal Consistency of the Nine Factors Identified from Factor Analysis}

To find out whether the three factors identified from each part of the questionnaire belong to the same dimension, the three dimensions were then each assessed for internal consistency using Cronbach alpha estimates. The $\alpha$ values were mostly 0.6 or above, which were acceptable or excellent internal reliability as 0.60 has long been regarded as a threshold of reliability for research purposes (Nunnally, 1978), and moderate correlation at 0.05 level of significance was found in most dimensions, which is considered evidence of discriminant validity (Netemeyer, 2003). All the nine factors were also assessed for internal consistency. The results show that while the majority of the factors showed significant correlations with mostly five or six other factors in both the pre-test (Table 2) and post-test (Table 3), the TDEP factor and the SOCSTR factor only showed significant correlations with one other factor in either the pre-test or the post-test. These results suggest that except for these two factors, most of the factors identified are likely to belong to the same overall construct. Of particular interest is the role of the factor of TDEP, since despite its week correlation with the other factors, it is the only factor in which all the three groups demonstrated common changes after the writing programme. This provides some insight into the role of this factor in the development of learner autonomy.

Table 2. Correlations among the nine factors in the pre-test

\begin{tabular}{|c|c|c|c|c|c|c|c|c|c|}
\hline & SELFDIR & MOTIV & TDEP & PEERFB & REVIS & PLANIN & DIRSTR & META & SOCSTR \\
\hline \multirow[t]{2}{*}{ SELFDIR } & 1 & $.39(* *)$ & -.10 & $.39(* *)$ & $.71(* *)$ & $.32(* *)$ & $.79(* *)$ & $.65(* *)$ & .11 \\
\hline & . & .001 & .427 & .001 & .000 & .007 & .000 & .000 & .379 \\
\hline \multirow[t]{2}{*}{ MOTIV } & $.40(* *)$ & 1 & .11 & $.30\left(^{*}\right)$ & $.37(* *)$ & .15 & $.49(* *)$ & $.47(* *)$ & .07 \\
\hline & .001 & . & .352 & .011 & .002 & .218 & .000 & .000 & .548 \\
\hline \multirow[t]{2}{*}{ TDEP } & -.10 & .11 & 1 & .19 & .10 & .10 & .01 & .01 & -.11 \\
\hline & .427 & .352 & . & .118 & .430 & .419 & .952 & .929 & .367 \\
\hline \multirow[t]{2}{*}{ PEERFB } & $.39(* *)$ & $.30\left(^{*}\right)$ & .19 & 1 & $.48(* *)$ & .17 & $.41(* *)$ & $.30\left(^{*}\right)$ & $.28(*)$ \\
\hline & .001 & .011 & .118 & . & .000 & .163 & .000 & .013 & .019 \\
\hline \multirow[t]{2}{*}{ REVIS } & $.71(* *)$ & $.37(* *)$ & .10 & $.48(* *)$ & 1 & $.38(* *)$ & $.69(* *)$ & $.54(* *)$ & .13 \\
\hline & .000 & .002 & .430 & .000 & . & .001 & .000 & .000 & .302 \\
\hline PLANING & $.32(* *)$ & .15 & .10 & .17 & $.38(* *)$ & 1 & $.39(* *)$ & $.34(* *)$ & -.06 \\
\hline
\end{tabular}




\begin{tabular}{llllllllll}
\hline & .007 & .218 & .419 & .163 & .001 &. & .001 & .004 & .647 \\
\hline DIRSTRA & $.80(* *)$ & $.49(* *)$ & .007 & $.41\left(^{* *}\right)$ & $.69\left(^{* *}\right)$ & $.39\left(^{* *}\right)$ & 1 & $.62(* *)$ & .09 \\
\hline META & .000 & .000 & .952 & .000 & .000 & .001 &. & .000 & .485 \\
\hline & .000 & .000 & .929 & .013 & .000 & .004 & .000 &. & .817 \\
\hline SOCSTR & .11 & .07 & -.11 & $.28(*)$ & .13 & -.06 & .09 & .03 & 1 \\
\hline & .379 & .548 & .367 & .019 & .302 & .647 & .485 & .817 &. \\
\hline
\end{tabular}

** Correlation is significant at the 0.01 level (2-tailed).

* Correlation is significant at the 0.05 level (2-tailed).

Table 3. Correlations among the nine factors in the post-test

\begin{tabular}{|c|c|c|c|c|c|c|c|c|c|}
\hline \multirow{2}{*}{$\overline{\text { SELFDIR }}$} & \multicolumn{2}{|c|}{ SELFDIR MOTIV } & \multirow{2}{*}{$\begin{array}{l}\text { TDEP } \\
-.13\end{array}$} & \multirow{2}{*}{$\begin{array}{l}\text { PEERFB } \\
.36(* *)\end{array}$} & \multirow{2}{*}{$\frac{\text { REVIS }}{.40\left(^{* *}\right)}$} & \multicolumn{3}{|c|}{ PLANINGDIRSTRA META } & \multirow{2}{*}{$\begin{array}{l}\text { SOCSTR } \\
.18\end{array}$} \\
\hline & 1 & $.38(* *)$ & & & & $.37(* *)$ & $.58(* *)$ & $.50(* *)$ & \\
\hline & . & .001 & .283 & .003 & .001 & .001 & .000 & .000 & .149 \\
\hline \multirow[t]{2}{*}{ MOTIV } & $.38(* *)$ & 1 & .14 & $.35(* *)$ & $.49(* *)$ & $.24(*)$ & $.41(* *)$ & $.27(*)$ & .12 \\
\hline & .001 & . & .251 & .003 & .000 & .041 & .000 & .026 & .329 \\
\hline \multirow[t]{2}{*}{ TDEP } & -.13 & .14 & 1 & $.43(* *)$ & .19 & -.11 & -.08 & .07 & -.10 \\
\hline & .283 & .251 & . & .000 & .195 & .369 & .512 & .570 & .403 \\
\hline \multirow[t]{2}{*}{ PEERFB } & $.36(* *)$ & $.35(* *)$ & $.43(* *)$ & 1 & $.51(* *)$ & .15 & $.42(* *)$ & $.34(* *)$ & .09 \\
\hline & .003 & .003 & .000 & . & .000 & .223 & .000 & .004 & .459 \\
\hline \multirow[t]{2}{*}{ REVIS } & $.40(* *)$ & $.49(* *)$ & .16 & $.51(* *)$ & 1 & $.32(* *)$ & $.61(* *)$ & $.41(* *)$ & .19 \\
\hline & .001 & .000 & .195 & .000 & . & .007 & .000 & .000 & .109 \\
\hline \multirow[t]{2}{*}{ PLANING } & $.37(* *)$ & $.24(*)$ & -.11 & .15 & $.32(* *)$ & 1 & $.40(* *)$ & $.26\left(^{*}\right)$ & $.34(* *)$ \\
\hline & .001 & .041 & .369 & .223 & .007 & . & .001 & .033 & .004 \\
\hline \multirow[t]{2}{*}{ DIRSTRA } & $.58(* *)$ & $.41(* *)$ & -.08 & $.42(* *)$ & $.61(* *)$ & $.40(* *)$ & 1 & $.66(* *)$ & .20 \\
\hline & .000 & .000 & .512 & .000 & .000 & .001 & . & .000 & .092 \\
\hline \multirow[t]{2}{*}{ META } & $.50(* *)$ & $.27(*)$ & .07 & $.34(* *)$ & $.41(* *)$ & $.26(*)$ & $.66(* *)$ & 1 & .05 \\
\hline & .000 & .026 & .570 & .004 & .000 & .033 & .000 & . & .670 \\
\hline \multirow[t]{2}{*}{ SOCSTR } & .18 & .12 & -.10 & .09 & .19 & $.34(* *)$ & .20 & .05 & 1 \\
\hline & .149 & .329 & .403 & .459 & .109 & .004 & .092 & .670 & . \\
\hline
\end{tabular}

** Correlation is significant at the 0.01 level (2-tailed).

* Correlation is significant at the 0.05 level (2-tailed).

\subsection{Changes in the Participants after the Writing Programme}

The paired-sample t-test results on the TDEP factor suggest that independence from the teacher was perhaps the first step in the development of learner autonomy in this group of learners. After the writing programme, when the same questionnaire was administered in each group to measure the participants' changes, the scores in this factor decreased by $0.36,0.47$ and 0.34 at 0.05 level of significance in Group 1, Group 2 and Group 3 respectively (see Appendix B). The common change in this one and only factor reveals that the growth of independence from the teacher may be the most immediate, conspicuous effect of the autonomy supporting pedagogical approach adopted in this study, though this change may not necessarily be accompanied by observable simultaneous development in other aspects of learner autonomy as conceptualized. This seems to indicate that independence from the teacher may be a necessary but insufficient condition for the growth of learner autonomy. 


\subsection{Correlations among Various Types of Motivation}

Meanwhile, results from the factor analysis show that while motivation may be ingrained in learner autonomy, only intrinsic motivation and the more self-determined types of extrinsic motivation play a role in learner autonomy and propel its development. These were manifested by the factor analysis results of Section 1 of the questionnaire.

The section included questions on a few common reasons for learning English writing, which fall into a spectrum of self-determination, ranging from extrinsic to intrinsic orientations (Deci \& Ryan, 1985). The three items on more self-determined forms of external regulation (Items 3-5) loaded on the same factor, named Motivation (MOTIV), with coefficient above 0.6 in both the pre-test and post-test, showing that the orientations were similar in nature (Table 4):

Table 4. Factor loadings for the factor of Motivation

\begin{tabular}{lllll}
\hline \multirow{2}{*}{ Factor } & $\begin{array}{l}\text { Item } \\
\text { no. }\end{array}$ & Item & \multicolumn{2}{c}{ Factor loadings } \\
\cline { 3 - 5 } & 3 & Learning English writing will help me find jobs in future. & Pre-test & Post-test \\
\cline { 2 - 5 } MOTIV & 4 & $\begin{array}{l}\text { I need to learn English writing in order to communicate with } \\
\text { foreigners. }\end{array}$ & .72 & .73 \\
\cline { 2 - 5 } & 5 & I learn to write because writing is an important skill. & .73 & .79 \\
\hline
\end{tabular}

However, the item about pure enjoyment of writing (Item 6) did not load on this factor; rather, it loaded on another factor, named Self-directedness (SELDIR), together with the items about self-confidence and self-initiated exploration of the writing process (Items 9 - 11) with coefficient above 0.5. The items about completely externally regulated learning (Items 1 and 2), which theoretically contradict the concept of learner autonomy, were found to correlate negatively with other items in this factor, with coefficient above 0.4 in both tests (Table 5).

Table 5. Factor loadings for the factor of Self-directedness

\begin{tabular}{lllll}
\hline \multirow{2}{*}{ Factor } & $\begin{array}{l}\text { Item } \\
\text { no. }\end{array}$ & & \multicolumn{2}{c}{ Factor loadings } \\
\cline { 3 - 5 } & 1 & $\begin{array}{l}\text { I seldom write in English except for school assignments, tests and } \\
\text { exams. }\end{array}$ & -.72 & \multicolumn{2}{c}{ Pre-test } & Post-test \\
\hline & & I learn to write mainly for exams & -.49 & -.47 \\
\cline { 2 - 5 } & 2 & I like writing in English & .64 & .69 \\
\cline { 2 - 5 } SELFDIR & 6 & $\begin{array}{l}\text { I have studied English writing by myself, and I have learnt a lot } \\
\text { from this. }\end{array}$ & .70 & .55 \\
\cline { 2 - 5 } & 9 & I believe I have the ability to learn English writing well. & .67 & .64 \\
\cline { 2 - 5 } & 10 & $\begin{array}{l}\text { I believe that I can push myself to improve my English writing } \\
\text { even if there is no supervision. }\end{array}$ & .69 & .84 \\
\hline
\end{tabular}

Although these items related to motivation were loaded on two distinct factors of Motivation and Self-directedness, they were nevertheless closely related as shown by the positive correlations between the two factors (Table 6): 
Table 6. Alpha reliability and correlations between the factors of MOTIV and SELFDIR

\begin{tabular}{lllll}
\hline Pre-test & & & MOTIV & SELDIR \\
\hline Dimension & No. of items & $\boldsymbol{\alpha}$ & 1 & $.32\left(^{* *}\right)$ \\
\hline MOTIV & 3 & .63 &. & .01 \\
\hline SELFDIR & 6 & .73 & $.32\left(^{* *}\right)$ & 1 \\
\hline & & .01 &. \\
\hline Post-test & & & MOTIV & SELDIR \\
\hline Dimension & No. of items & $\boldsymbol{\alpha}$ & 1 & $.25\left(^{*}\right)$ \\
\hline MOTIV & 3 & .61 &. & .04 \\
\hline SELFDIR & 6 & & $.25\left(^{*}\right)$ & 1 \\
\hline
\end{tabular}

** Correlation is significant at the 0.05 level (2-tailed).

\section{Findings and Discussion}

\subsection{An Integrated Theoretical Framework of Learner Autonomy}

By addressing the first research question, the findings above provide empirical support for the proposed construct of learner autonomy in writing. Factor analysis of Section 1 found that more self-determined types of external regulation correlated with self-directedness, while intrinsic motivation and self-confidence were embedded in self-directedness. Factor analysis of Section 2, which focused on general writing strategies, showed that the factors of peer feedback, revision and planning were positively correlated, suggesting that the use of these strategies by young learners are to a certain extent interrelated. In Section 3, the factor of direct strategies for learning writing correlated positively with the factor of metacognitive strategies and knowledge, which provides some evidence in support of the close relationship between metacognitive knowledge and learning strategies, including both metacognitive and direct learning strategies. Seven out of the nine factors identified in the factor analysis mentioned above was found to be positively correlated with most other factors in both the pre-test and post-test at 0.05 level of significance, showing a high probability that these factors belong to the same construct of learner autonomy. The theoretical proposition of the construct was therefore generally supported by results of the factor analysis of the three sections of the questionnaire.

However, the relatively weak correlations of the factors of Degree of Dependence on the Teacher and of Social Strategy Use with the other factors in the construct need further examination. Concerning social strategies, although they are one kind of learning strategies, its weak correlation with the other factors raises the question whether the tendency to use social strategies is a reliable indicator of the development of learner autonomy. Social strategy use was incorporated in the construct because- while self-reliance could be taken as a sign of development of learner autonomy, learner autonomy may also develop through learner interdependence rather than independence. In an explicitly social-interactive pedagogy, individual language learning or language use usually leads the learner back towards further collaborative activity (Little, 2000), and given time, social isolation may provide sufficient motivation for renewed efforts at functioning within a group even for those who previously did not get along (Crandall, 1999, p. 241). The use of social strategies, however, tends to be affected by contexts as demonstrated in various studies (e.g. Harish, 2014; Salahshour, Sharifi, \& Salahshour, 2012). The idiosyncrasy of the use of social strategies and its subjectivity to contextual and individual differences may explain why this factor does not correlate very well with the other factors in the construct. The use of social strategies as a manifestation of learner autonomy should therefore be considered more judiciously than other types of learning strategies.

\subsection{The Role of the Factor of Independence from Teacher and Other Factors of the Construct of Learner Autonomy}

Meanwhile, the weak correlation between the Degree of Dependence on the Teacher factor and other factors brought up the question about the role this factor should play in learner autonomy. A belief commonly held by 
advocates of learner autonomy, as mentioned, is that to get learners prepared for taking up the responsibility for their own learning, the first thing teachers have to do is learn to relinquish control in the classroom and help learners gradually develop the capacity to direct their own learning. The underlying assumption is that the responsibility for learning is shared between the teacher and the students, and if one party takes up more of it, the other could or would have to let go some of it accordingly. This appears to be a rather simplistic view given the complexity of the interaction in the classroom. As Woods (2006) put it:

An important issue in the thinking of teachers in many second and foreign language classrooms, although often implicit, is the issue of who is going to do what - how much of the responsibility and the decision-making and work is going to be done by the teacher, and how much is going to be done by the learners? The language teaching literature also reflects this concern: the movement to learner autonomy (Benson, 2001; Riley, 1988) and learner training (O'Malley and Chamot, 1990; Wenden and Rubin, 1987) is based on the idea that it is beneficial to teach learners to take more responsibility for their own language learning. ... When the question...is examined closely, it begins to become clear that it is not in principle answerable. The process of deciding appears more and more as a dynamically evolving interaction, with constantly changing rules. (Woods, 2006, p. $88)$.

The question about negotiated responsibility for decision-making, framed in terms of the notion of "planning" in the language classroom, has thus far not been widely investigated in the literature (Woods, 2006), and yet it presents a new perspective that acknowledges the interactional complexity of the language classroom. It may be argued that independence from the teacher may not necessarily lead to self-directed learning, and even autonomous learners may appreciate the teacher's help. In fact, the role of the teacher is one of the areas where learners can make decisions regarding their own learning (Benson, 2002). Teachers are often considered to take up the roles of facilitators (e.g. Boud, 1988; Knowles, 1975; Sheerin, 1991; Stevick, 1976) and resource persons (e.g. Wright, 1987), as well as consultants and counsellors. No matter what role the learner assigns the teacher, "there is a paradox about the teacher's role in independent learning; the truly autonomous learner would not need a teacher at all. Equally, autonomy is not a gift that can be handed over by the teacher to the learner" (Benson \& Voller, 1997, 107).

Because of such complexity, it is not easy to identify "sure" signs of independence from the teacher. However, no matter how the teacher's role is understood, learner's expectation of being hand held by the teacher should be mutually exclusive with learner autonomy. The three items that loaded on the Degree of Dependence on the Teacher factor, "I like the teacher to tell me what to write about", "The teacher should explain in detail the requirements of each writing task" and "When we write, the teacher should provide model essays as well as vocabulary and sentence patterns related to the topic for our reference", clearly reflected the learner's expectation of "spoon-feeding", in other words extreme dependence on the teacher. Any decrease in this factor could reasonably be attributed to dwindling dependence on the teacher, and thus a step further in the development of learner autonomy.

This result from the factor analysis, coupled with the participants' decrease in the score on the Degree of Dependence on the Teacher factor in the post-test, suggests that independence from the teacher, though it may not covary with other factors in the construct of learner autonomy, is nevertheless a pre-cursor or necessary condition for learner autonomy to develop.

\subsection{The Role of Motivation in the Overall Development of Learner Autonomy}

Results from the factor analysis provided some evidence concerning the roles of different types of motivation in the construct of learner autonomy. Since "the intrinsic urge to explore and master the world of one's surroundings is characteristic of developmental learning and fundamentally shapes autonomous learning" (Dornyei, 2005, p. 41), it follows that only the more self-determined forms of regulation showed positive correlations with self-directedness. This means that while motivation is part of the construct of learner autonomy, the type of motivation in play must also be taken into account: only the more self-determined types of regulation appear to correlate with the other factors of learner autonomy; purely intrinsic motivation, together with self-confidence, is not only related to but may also be facets of self-initiation.

In addition, even though the correlation between intrinsic motivation and external regulation for learning may not prove to be very significant in some studies (e.g. Noels et al., 2003), a negative correlation may exist between them in relation to self-initiated learning on theoretical grounds (e.g. Van Lier, 1996), and this was found to be the case. These suggested that purely extrinsically motivated individuals, though in theory motivated, may not become autonomous learners because of the lack of self-directedness. The clustering of the items about motivation into two factors suggests that autonomous learning may require both intrinsic orientation and more 
self-determined types of motivation. Intrinsic orientations alone may not automatically lead to engagement in the learning process; the learner may also need to be persuaded that it is personally important for them (Noels et al., 2003). In other words, these different types of motivation coexist and yet have different roles to play in autonomous learning.

The types of motivation in play also have profound effects on the learning process by determining the depth of cognitive processing during the learning process. Motivation is responsible for why people decide to do something, how long they are willing to sustain the activity, and how hard they are going to pursue it (Dornyei, 2000). Whereas extrinsically motivated learners attend to only the surface characteristics of the input, and subsequently do not process it deeply, intrinsic motivation endorses deep processing, which entails greater elaboration and thus greater cognitive effort (Manolopoulou-Sergi, 2004), and creative writers are also intrinsically motivated writers who can engage the task fully and enter a state of creative flow (Amabile, 1985). This may explain why motivated learners show higher use of metacognitive strategies and development in their metacognitive knowledge at the same time, thus the positive correlations among these factors.

\subsection{The Development of Learner Autonomy as a Function of Independence from the Teacher and more Self-Determined Types of Motivation}

When the roles of the teacher and of various kinds of motivation are viewed together, it seems that the two factors work in a complementary manner, possibly at different developmental stages of learner autonomy. As Vygotsky's Zone of Proximal Development would imply, the autonomy that we achieve at one stage provides an essential springboard to the next (Little, 2004); from this point of view, it is not surprising to find that learner autonomy may develop in stages with certain pre-requisites for each. Nunan's (1995) five levels of learner-centredness shared a similar view, with awareness, involvement and intervention as the earlier stages where the teacher has a more important guiding role to play, followed by the stage of creation where one of the main roles of the teacher is as a motivator and finally the stage of transcendence in which the teacher becomes more of an advisor or monitor while the students take control of most aspects of their learning. Nunan's five levels of learner autonomy, though mainly focusing on the teacher's role, do acknowledge the importance of motivation in the later levels of autonomy development. The present study therefore provides further empirical support of the possible stages of development of learner autonomy, with motivation being a key player.

It leads to the subsequent question: what are the roles of motivation and independence from the teacher in the development of learner autonomy? As discussed earlier, concerning the role of motivation, only motivation of a more self-determined nature correlates with self-initiation and constitutes autonomous attitudes. The presence of the right kind of motivation may therefore be a necessary condition for fully-fledged development in all other aspects of learner autonomy, while independence from the teacher may be necessary and yet not sufficient. The developmental stages could be conjectured as a function between motivation and dependence on the teacher:

Stage 1: Low motivation, high dependence on the teacher

Stage 2: Moderate motivation, falling dependence on the teacher

Stage 3: High motivation, increasing willingness to take up the responsibility of learning

These proposed stages are rather broad and apparently not clear-cut; it may also be argued that motivation does not necessarily grow with independence from the teacher. However, as with other kinds of development, progress is not a matter of course; the autonomous attributes in a learner may reach and stay at a certain stage with little change afterwards. As motivation can be considered a propellant of the development of learner autonomy, the lack of motivation would mean stagnancy. The proposed stages are therefore only meant to illustrate the possible relationship between motivation and independence from the teacher in the development of learner autonomy, in the hope that it will inspire further investigation in this direction.

\section{Conclusion}

Findings from the study indicate that the proposed construct of learning autonomy in writing largely holds, at least among young ESL learners of backgrounds similar to those of the student participants of this study, though the factor of degree of dependence on the teacher warrants further examination. The relatively weak correlation between this factor and the other factors in the construct seems to suggest it does not belong; however, the decrease in reliance on the teacher among the three groups of participants after a writing programme designed to encourage the development of learner autonomy provides some evidence to suggest that independence from the teacher may be a pre-condition for the development of learner autonomy. In other words, the growth of independence from the teacher may not be a sufficient condidtion for a learner to become autonomous, but it may be the first necessary change to take place in the process. 
Meanwhile, the findings illustrate the importance of not only the existence of but also the types of motivation in the overall development of learner autonomy in writing. In short, purely intrinsic motivation is necessary for self-initiation, while the existence of more self-determined types of external motivation positively affects the development of learner autonomy. Putting all these together, it seems that independence from the teacher provides the ignition, and the right kinds of motivation may be regarded as the fuel for this developmental journey.

The findings from the study have pedagogical implications. Since independence from the teacher is the first step towards learner autonomy in writing, and since more intrinsic types of motivation are necessary for later development, the fostering of these two attributes should be important goals in curriculum design and teaching practices. Pedagogical practices encouraging self-reflection and peer feedback, such as the one adopted in this study, seem to be effective in encouraging learner independence. Other strategies, such as the use of learning tasks that are fun and relevant to the students' lives and the building of an autonomy supporting environment in general, may also help to foster learner motivation and autonomy.

The interplay of the factors of independence from the teacher and motivation, as well as the possible existence of developmental stages of learner autonomy among different age groups, may also deserve more consideration in actual teaching practice and future research. Although the generalizability of the findings may be compromised by the small sample size and the high contextuality of the study, it is hoped the study will lay some ground work for further investigations that will lead to a better understanding of the construct of learner autonomy and its manifestation. Such investigations will contribute to the achievement of this desirable educational goal.

\section{References}

Amabile, T. M. (1985). Motivation and creativity: Effects of motivational orientation on creative writers. Journal of Personality and Social Psychology, 48, 393-399. http://dx.doi.org/10.1037/0022-3514.48.2.393

Benson, P. (1996). Concepts of autonomy in language learning. In R. Pemberton (Ed.), Taking control: Autonomy in language learning. Hong Kong: Hong Kong University Press.

Benson, P. (2001). Teaching and researching autonomy in language learning. Harlow; Hong Kong: Longman.

Benson, P. (2002). Autonomy and communication. In P. Benson \& S. Toogood (Eds.), Learner autonomy 7: Challenges to research and practice (pp. 10-28). Dublin: Authentik Language Learning Resources Ltd.

Benson, P., \& Toogood, S. (Eds.). (2002). Learner autonomy 7: Challenges to research and practice. Dublin: Authentik Language Learning Resources Ltd.

Benson, P., \& Voller, P. (Eds.). (1997). Autonomy and independence in language learning. London; New York: Longman.

Boud, D. (Ed.). (1988). Developing student autonomy in learning. New York: Kogan Press.

Cottrell, S. (1995). Readiness for autonomy: Investigating learner beliefs. System, 23(2), 195-205. http://dx.doi.org/10.1016/0346-251X(95)00008-8

Crabbe, D. A. (1993). Fostering autonomy from within the classroom: The teacher's responsibility. System, 21, 443-452. http://dx.doi.org/10.1016/0346-251X(93)90056-M

Crandall, J. (1999). Cooperative language learning and affective factors. In J. Arnold (Ed.), Affect in language learning (pp. 226-245). Cambridge: Cambridge University Press.

Deci, E. L., \& Ryan, R. M. (1985). Intrinsic motivation and self-determination in human behavior. New York: Plenum Press. http://dx.doi.org/10.1007/978-1-4899-2271-7

Dickinson, L. (1987). Self-Instruction in Language Learning. Cambridge. Cambridge University Press.

Dickinson, L. (1995) Autonomy and motivation: A literature review. System, 23(2), 165-174. http://dx.doi.org/10.1016/0346-251X(95)00005-5

Dickinson, L. (1992). Learner training for language learning. Dublin: Authentik Language Learning Resources.

Dornyei, Z. (2000). Motivation in action: Towards a process-oriented conceptualisation of student motivation. British Journal of Educational Psychology, 70, 519-538. http://dx.doi.org/10.1348/000709900158281

Dörnyei, Z. (2003). Attitudes, orientations, and motivations in language learning: advances in theory, research, and applications. Malden, MA; Oxford, UK: Blackwell.

Flower, L., \& Hayes, J. (1981). A cognitive process theory of writing. College Composition and Communication, 32, 365-387. http://dx.doi.org/10.2307/356600 
Haris, S. (2014). Social strategy use and language learning contexts: A case study of Malayalee undergraduate students in India. System, 43, 64-73. http://dx.doi.org/10.1016/j.system.2014.01.002

Holec, H. (1981). Autonomy and foreign language learning. Oxford: Pergamon Press.

Knowles, M. S. (1975). Self-directed Learning. New York: Association Press.

Lamb, T., \& Reinders, H. (Eds.). (2008). Learner and teacher autonomy: Concepts, realities, and responses. Amsterdam: John Benjamins. http://dx.doi.org/10.1075/aals.1

Little, D. (2004). Constructing a theory of learner autonomy: some steps along the way. Future perspectives in foreign language education, 15-25.

Little, D. (2007). Introduction: Reconstructing learner and teacher autonomy in language education. Reconstructing autonomy in language education: Inquiry and innovation, 1-12. http://dx.doi.org/10.1057/9780230596443_1

Little, D. (1991). Learner autonomy: Definitions, issues and problems. Dublin: Authentik Language Learning Resources.

Little, D. (2000). Learner autonomy and human interdependence: Some theoretical and practical consequences of a social-interactive view of cognition, learning and language. Harlow: Longman.

Littlewood, W. (1996). "Autonomy": An anatomy and a framework. System, 24(4), 427-435. http://dx.doi.org/10.1016/S0346-251X(96)00039-5

Manolopoulou-Sergi, E. (2004). Motivation within the information processing model of foreign language learning. System, 32, 427-441. http://dx.doi.org/10.1016/j.system.2004.04.002

Mayer, R. E. (2002). Teaching for meaningful learning. Upper Saddle River, NJ: Prentice-Hall. http://dx.doi.org/10.1002/t1.47

Netemeyer, R. G., Bearden, W. O., \& Sharma, S. (2003). Scaling procedures: Issues and applications. Thousand Oaks, CA: Sage. http://dx.doi.org/10.4135/9781412985772

Noels, K. A., Pelletier, L. G., \& Vallerand, R. J. (2003). Why are you learning a second language? Motivational orientations and self-determination theory. In Z. Dörnyei (Ed.), Attitudes, orientations, and motivations in language learning: Advances in theory, research, and applications (pp. 33-62). Malden, MA; Oxford, UK: Blackwell. http://dx.doi.org/10.1111/1467-9922.53223

Nunan, D. (1995). Closing the gap between learning and instruction. TESOL Quarterly, 29(1), 133-158. http://dx.doi.org/10.2307/3587808

Nunnally, J. C. (1978). Psychometric theory (2nd ed.). New York: McGraw-Hill.

O'Malley, J. M., \& Chamot, A. U. (1990). Learning strategies in second language acquisition. Cambridge: Cambridge University Press. http://dx.doi.org/10.1017/CBO9781139524490

Oxford, R. L. (1990). Language learning strategies: What every teacher should know. Boston: Heinle \& Heinle.

Oxford, R. L. (2003). Toward a more systematic: Model of L2 learner autonomy. In D. Palfreyman \& R. C. Smith (Eds.), Learner autonomy across cultures: Language education perspectives. Basingstoke, Hampshire; New York, NY: Palgrave Macmillan. http://dx.doi.org/10.1057/9780230504684_5

Pedhazur, E. J., \& Schmelkin, L. P. (1991). Measurement, Design, and Analysis: An Integrated Approach. Hillsdale, NJ: Lawrence Erlbaum Associates.

Riley, P. (1988). The ethnography of autonomy. In A. Brookes \& P. Grundy (Eds.), Individualization and Autonomy in Language Learning (pp. 12-34). London: British Council.

Salahshour, F., Sharifi, M., \& Salahshour, N. (2012). The relationship between language learning strategy use, language proficiency level and learner gender. Procedia - Social and Behavioural Sciences, 70, 634-643. http://dx.doi.org/10.1016/j.sbspro.2013.01.103

Scharle, Á., \& Szabó, A. (2000). Learner autonomy: A guide to developing learner responsibility. Cambridge: Cambridge University Press.

Sheerin, S. (1991). State of the art self-access. Language Teaching, 24(3), 143-157. http://dx.doi.org/10.1017/S0261444800006315

Sheerin, S. (1997). An exploration of the relationship between self-access and independent learning. In P. Benson \& P. Voller (Eds.), Autonomy and independence in language learning (pp. 54-65). London: Longman. 
Spratt, M., Humphreys, G., \& Chan, V. (2002). Autonomy and motivation: Which comes first? Language Teaching Research, 6, 245-266. http://dx.doi.org/10.1191/13621688021r106oa

Stevick, E. W. (1976). Memory, meaning and method. Rowley, MA: Newbury House.

Tanyeli, N., \& Kuter, S. (2013). Examining learner autonomy in foreign language learning and instruction. Egitim Arastirmalari-Eurasian Journal of Educational Research, 53, 19-36.

Tassinari, M. G. (2012). Evaluating learner autonomy: A dynamic model with descriptors. Studies in Self-Access Learning Journal, 3(1), 24-40.

Ushioda, E. (1996). The role of motivation. Dublin: Authentik Language Learning Resources.

Ushioda, E. (2003). Motivation as a socially mediated process. In D, Little, J, Ridley, \& E. Ushioda (Eds.), Learner autonomy in the foreign language classroom: Teacher, learner, curriculum and assessment. Dublin: Authentik

Van Lier, L. (1996). Interaction in the language curriculum: Awareness, autonomy, and authenticity. London: Longman.

Van Oers, B. (1998). From context to contextualizing. Learning and Instructions, 8(6), 473-488. http://dx.doi.org/10.1016/S0959-4752(98)00031-0

Veronikas, S., \& Shaughnessy, M. (2005). An interview with Richard Mayer. Educational Psychology Review, 17(2), 179-190. DOI: http://dx.doi.org/10.1007/s10648-005-3952-z

Wenden, A. (1991). Learner strategies for learner autonomy: Planning and implementing learner training for language learners. New York: Prentice Hall.

Wenden, A. (1998). Metacognitive knowledge and language learning. Applied Linguistics, 19(4), 515-537. http://dx.doi.org/10.1093/applin/19.4.515

Wenden, A., \& Rubin, J. (Eds.). (1987). Learner strategies in language learning. Englewood Cliffs, NJ: Prentice Hall. http://dx.doi.org/10.1111/j.1467-1770.1987.tb00585.x

Woods, D. (2006). Who does what in the 'management of language learning'? Planning and the social construction of the 'motivation to notice'. In S. Gieve, \& I. K. Miller (Eds.), Understanding the language classroom (pp. 88-114). New York: Palgrave Macmillan. http://dx.doi.org/10.1057/9780230523166_6

Wright, T. (1987). Roles of teachers and learners. Oxford: Oxford University Press.

Appendix A. Item-total correlations of the various factors identified in the factor analysis

Pre-test

\begin{tabular}{|l|l|l|l|l|}
\hline \multirow{5}{*}{ Dimension } & \multirow{2}{*}{ Item } & \multicolumn{2}{l|}{ Factor loadings } \\
\cline { 2 - 5 } & & $\mathbf{1}$ & $\mathbf{2}$ & $\mathbf{3}$ \\
\hline \multirow{5}{*}{ SELFDIR } & $\begin{array}{l}\text { I seldom write in English except for school assignments, tests and } \\
\text { exams. }\end{array}$ & -.72 & & \\
& I learn to write mainly for exams & -.49 & & \\
\cline { 2 - 5 } & I like writing in English & .64 & & \\
\hline & $\begin{array}{l}\text { I have studied English writing by myself, and I have learnt a lot from } \\
\text { this. }\end{array}$ & .70 & & \\
\cline { 2 - 5 } & I believe I have the ability to learn English writing well. & .67 & & \\
\cline { 2 - 5 } & $\begin{array}{l}\text { I believe that I can push myself to improve my English writing even } \\
\text { if there is no supervision. }\end{array}$ & .69 & & \\
\hline \multirow{5}{*}{ MOTIV } & Learning English writing will help me find jobs in future. & & .72 & \\
\hline & $\begin{array}{l}\text { I need to learn English writing in order to communicate with } \\
\text { foreigners. }\end{array}$ & .71 & \\
\cline { 2 - 5 } & I learn to write because writing is an important skill. & & .73 & .81 \\
\hline \multirow{2}{*}{ TDEP } & I like the teacher to tell me what to write about. & & & \\
\hline
\end{tabular}




\begin{tabular}{|l|l|l|l|l|}
\hline & $\begin{array}{l}\text { The teacher should explain in detail the genre requirements of each } \\
\text { writing task. }\end{array}$ & & & .66 \\
\cline { 2 - 5 } & $\begin{array}{l}\text { When we write, the teacher should provide model essays as well as } \\
\text { vocabulary and sentence patterns related to the topic for our } \\
\text { reference. }\end{array}$ & & .84 \\
\hline Eigenvalues & & 3.27 & 2.07 & 1.39 \\
\hline $\begin{array}{l}\text { Variance } \\
\text { explained }\end{array}$ & & 27.26 & 17.26 & 11.55 \\
\hline
\end{tabular}

Post-test

\begin{tabular}{|c|c|c|c|c|}
\hline \multirow{2}{*}{ Dimension } & \multirow{2}{*}{ Item } & \multicolumn{3}{|c|}{ Factor loadings } \\
\hline & & 1 & 2 & 3 \\
\hline \multirow{6}{*}{ SELFDIR } & $\begin{array}{l}\text { I seldom write in English except for school assignments, tests and } \\
\text { exams. }\end{array}$ & -.69 & & \\
\hline & I learn to write mainly for exams & -.47 & & \\
\hline & I like writing in English & .69 & & \\
\hline & $\begin{array}{l}\text { I have studied English writing by myself, and I have learnt a lot from } \\
\text { this. }\end{array}$ & .55 & & \\
\hline & I believe I have the ability to learn English writing well. & .64 & & \\
\hline & $\begin{array}{l}\text { I believe that I can push myself to improve my English writing even if } \\
\text { there is no supervision. }\end{array}$ & .84 & & \\
\hline \multirow{3}{*}{ MOTIV } & Learning English writing will help me find jobs in future. & & .73 & \\
\hline & $\begin{array}{l}\text { I need to learn English writing in order to communicate with } \\
\text { foreigners. }\end{array}$ & & .65 & \\
\hline & I learn to write because writing is an important skill. & & .79 & \\
\hline \multirow{3}{*}{ TDEP } & I like the teacher to tell me what to write about. & & & .83 \\
\hline & $\begin{array}{l}\text { The teacher should explain in detail the genre requirements of each } \\
\text { writing task. }\end{array}$ & & & .66 \\
\hline & $\begin{array}{l}\text { When we write, the teacher should provide model essays as well as } \\
\text { vocabulary and sentence patterns related to the topic for our reference. }\end{array}$ & & & .70 \\
\hline Eigenvalues & & 3.24 & 1.89 & 1.58 \\
\hline $\begin{array}{l}\text { Variance } \\
\text { explained }\end{array}$ & & 27.03 & 15.76 & 13.15 \\
\hline
\end{tabular}

Note: Loadings >.4 are reported. 
Appendix B. Results of paired-samples t-tests

Group 1

\begin{tabular}{|c|c|c|c|c|c|c|c|c|}
\hline & \multicolumn{5}{|c|}{ Paired Differences } & \multirow{3}{*}{$\begin{array}{l}\text { Sig. } \\
\text { (2-tailed) }\end{array}$} \\
\hline & & & \multirow{2}{*}{ Mean } & \multirow{2}{*}{$\begin{array}{l}\text { Std. } \\
\text { Deviation }\end{array}$} & \multirow{2}{*}{$\begin{array}{ll}\text { Std. } & \text { Error } \\
\text { Mean } & \end{array}$} & \multicolumn{2}{|c|}{$\begin{array}{l}95 \% \text { Confidence Interval of } \\
\text { the Difference }\end{array}$} & \\
\hline & & & & & & Lower & Upper & \\
\hline Pair 1 & $\begin{array}{l}\text { MOTIV2 } \\
\text { MOTIV1 }\end{array}$ & - & .20 & .55 & .10 & -.01 & .41 & .056 \\
\hline Pair 2 & $\begin{array}{l}\text { SELFDIR2 } \\
\text { SELFDIR1 }\end{array}$ & - & .07 & .56 & .10 & -.14 & .28 & .499 \\
\hline Pair 3 & $\begin{array}{l}\text { TDEP2 } \\
\text { TDEP1 }\end{array}$ & - & -.36 & .81 & .15 & .05 & .66 & . 022 \\
\hline Pair 4 & $\begin{array}{l}\text { REVIS2 } \\
\text { REVIS1 }\end{array}$ & - & -.03 & .64 & .12 & -.26 & .22 & .866 \\
\hline Pair 5 & $\begin{array}{l}\text { PEERFB2 } \\
\text { PEERFB1 }\end{array}$ & - & .18 & .64 & .12 & -.06 & .41 & .143 \\
\hline Pair 6 & $\begin{array}{l}\text { PLANING2 } \\
\text { PLANING1 }\end{array}$ & - & -.07 & 1.07 & .20 & -.47 & .33 & .736 \\
\hline Pair 7 & $\begin{array}{l}\text { DIRSTRA2 } \\
\text { DIRSTRA1 }\end{array}$ & - & .10 & .41 & .08 & -.06 & .25 & .216 \\
\hline Pair 8 & $\begin{array}{l}\text { META2 } \\
\text { META1 }\end{array}$ & - & .05 & .48 & .09 & -.13 & .23 & .599 \\
\hline Pair 9 & $\begin{array}{l}\text { SOCIAL2 } \\
\text { SOCIAL1 }\end{array}$ & - & .38 & .10 & .189 & .01 & .76 & .044 \\
\hline
\end{tabular}

Group 2

\begin{tabular}{|c|c|c|c|c|c|c|c|}
\hline & \multicolumn{5}{|c|}{ Paired Differences } & \multirow{3}{*}{$\begin{array}{l}\text { Sig. } \\
\text { (2-tailed) }\end{array}$} \\
\hline & & \multirow[t]{2}{*}{ Mean } & \multirow{2}{*}{$\begin{array}{l}\text { Std. } \\
\text { Deviation }\end{array}$} & \multirow{2}{*}{$\begin{array}{l}\text { Std. Error } \\
\text { Mean }\end{array}$} & \multicolumn{2}{|c|}{$\begin{array}{l}95 \% \text { Confidence Interval of } \\
\text { the Difference }\end{array}$} & \\
\hline & & & & & Lower & Upper & \\
\hline Pair 1 & $\begin{array}{l}\text { MOTIV2 } \\
\text { MOTIV1 }\end{array}$ & .10 & .56 & .13 & -.16 & .35 & .443 \\
\hline Pair 2 & $\begin{array}{l}\text { SELFDIR2 } \\
\text { SELFDIR1 }\end{array}$ & .06 & .69 & .15 & -.25 & .38 & .674 \\
\hline Pair 3 & $\begin{array}{l}\text { TDEP2 } \\
\text { TDEP1 }\end{array}$ & -.47 & .82 & .19 & .09 & .85 & .019 \\
\hline Pair 4 & $\begin{array}{l}\text { REVIS2 } \\
\text { REVIS1 }\end{array}$ & .10 & .67 & .14 & -.21 & .41 & .497 \\
\hline Pair 5 & $\begin{array}{l}\text { PEERFB2 } \\
\text { PEERFB1 }\end{array}$ & -.06 & .59 & .13 & -.33 & .21 & .647 \\
\hline Pair 6 & $\begin{array}{l}\text { PLANING2 } \\
\text { PLANING1 }\end{array}$ & -.26 & 1.05 & .23 & -.74 & .21 & .264 \\
\hline Pair 7 & $\begin{array}{l}\text { DIRSTRA2 } \\
\text { DIRSTRA1 }\end{array}$ & -.12 & .59 & .13 & -.39 & .15 & .359 \\
\hline Pair 8 & $\begin{array}{l}\text { META2 } \\
\text { META1 }\end{array}$ & .12 & .64 & .14 & -.17 & .41 & .404 \\
\hline Pair 9 & $\begin{array}{l}\text { SOCIAL2 } \\
\text { SOCIAL1 }\end{array}$ & -.45 & .99 & .22 & -.90 & -.00 & .048 \\
\hline
\end{tabular}


Group 3

\begin{tabular}{|c|c|c|c|c|c|c|c|c|}
\hline & \multicolumn{5}{|c|}{ Paired Differences } & \multirow{3}{*}{$\begin{array}{l}\text { Sig. } \\
\text { (2-tailed) }\end{array}$} \\
\hline & & & \multirow[t]{2}{*}{ Mean } & \multirow{2}{*}{$\begin{array}{l}\text { Std. } \\
\text { Deviation }\end{array}$} & \multirow{2}{*}{$\begin{array}{l}\text { Std. Error } \\
\text { Mean }\end{array}$} & \multicolumn{2}{|c|}{$\begin{array}{l}\text { 95\% Confidence Interval of } \\
\text { the Difference }\end{array}$} & \\
\hline & & & & & & Lower & Upper & \\
\hline Pair 1 & $\begin{array}{l}\text { MOTIV2 } \\
\text { MOTIV1 }\end{array}$ & - & .17 & .62 & .14 & -.13 & .47 & .249 \\
\hline Pair 2 & $\begin{array}{l}\text { SELFDIR2 } \\
\text { SELFDIR1 }\end{array}$ & - & -.12 & .47 & .11 & -.35 & .11 & .291 \\
\hline Pair 3 & $\begin{array}{l}\text { TDEP2 } \\
\text { TDEP1 }\end{array}$ & - & -.34 & .64 & .15 & .03 & .65 & .032 \\
\hline Pair 4 & $\begin{array}{l}\text { REVIS2 } \\
\text { REVIS1 }\end{array}$ & - & .00 & .52 & .12 & -.25 & .25 & 1.000 \\
\hline Pair 5 & $\begin{array}{l}\text { PEERFB2 } \\
\text { PEERFB1 }\end{array}$ & - & .00 & .61 & .14 & -.29 & .23 & 1.000 \\
\hline Pair 6 & $\begin{array}{l}\text { PLANING2 } \\
\text { PLANING1 }\end{array}$ & - & .03 & .66 & .15 & -.29 & .34 & .863 \\
\hline Pair 7 & $\begin{array}{l}\text { DIRSTRA2 } \\
\text { DIRSTRA1 }\end{array}$ & - & -.05 & .43 & .10 & -.26 & .16 & .610 \\
\hline Pair 8 & $\begin{array}{l}\text { META2 } \\
\text { META1 }\end{array}$ & - & .19 & .52 & .12 & -.06 & .44 & .131 \\
\hline Pair 9 & $\begin{array}{l}\text { SOCIAL2 } \\
\text { SOCIAL1 }\end{array}$ & - & -.03 & .63 & .15 & -.34 & .29 & .854 \\
\hline
\end{tabular}

\section{Copyrights}

Copyright for this article is retained by the author(s), with first publication rights granted to the journal.

This is an open-access article distributed under the terms and conditions of the Creative Commons Attribution license (http://creativecommons.org/licenses/by/4.0/). 